\title{
Dietary levels of lysine for male broilers from 23 to 36 days of age: performance and body composition ${ }^{1}$
}

\author{
Messias Alves da Trindade Neto ${ }^{2}$, Ana Louise de Toledo ${ }^{3}$, Paula Takeara ${ }^{3}$, Estela \\ Kobashigawa $^{3}$, Daniella Carolina Zanardo Donato ${ }^{3}$, Ricardo de Albuquerque $^{2}$
}

1 Financimento parcial da Fundação de Apoio à Pesquisa Agrícola (FUNDAG).
2 Departamento de Nutrição e Produção Animal da FMVZ-USP, SP, Brasil.
3 Programa de Pós-Graduação em Nutrição e Produção Animal, FMVZ/USP, SP, Brasil.

ABSTRACT - One thousand and fifty $(1,050)$ Ross male broilers from 23 to 36 days of age were used to evaluate the dietary effects of levels of lysine. It was used a random block design with 5 levels of digestible lysine $(0.95 ; 1.00 ; 1.05 ; 1.10$ and $1.15 \%)$. Each level was applied to seven replicates and the experimental unit was composed of 30 birds. Diets were offered in seven replicates and the experimental unit was represented by 30 birds. Weight gain, feed intake, feed conversion, carcass traits, cut yields, composition and deposition of body nutrients were evaluated. The concentration of $1.09 \%$ of digestible lysine optimized performance without significant effects on feed intake. Carcass traits and cut yields had no significant differences among levels of lysine. On the other hand, there was a quadratic effect on carcass weight, which was the best at the level of $1.07 \%$ of digestible lysine. On crude protein content of the empty body, the best response was observed at the level of $1.10 \%$ of dietary lysine. This same level corresponded to a quadratic response in the deposition of water from carcass and empty body. The level of digestible lysine for better performance, chemical composition and body nutrient deposition in broilers from 23 to 36 days of age is between 1.07 and $1.10 \%$.

Key Words: digestible amino acid, nutrient depositions, nutrition, requirement

\section{Níveis dietéticos de lisina para frangos de corte machos, dos 23 aos 36 dias de idade: desempenho e composição corporal}

RESUMO - Mil e cinquenta (1050) frangos de corte machos, linhagem Ross, dos 23 aos 36 dias de idade foram usados para avaliar os efeitos dieteticos do nivel de lisina. O delineamento experimental foi de blocos casualizados, com 5 níveis de lisina digestível $(0,95 ; 1,00 ; 1,05 ; 1,10$ e $1,15 \%)$. Cada nível foi aplicado a 7 repetições e a unidade experimental foi composta por 30 aves. As dietas foram oferecidas em sete repetições e a unidade experimental foi representada por 30 aves. Foram avaliados o ganho de peso, o consumo de ração, a conversão alimentar, as características de carcaça, o rendimento de cortes, a composição e a deposição de nutrientes corporais. A concentração de 1,09\% de lisina digestível maximizou o desempenho sem efeitos significativos sobre o consumo de ração. As características de carcaça e os rendimentos dos cortes não tiveram diferenças significativas entre níveis de lisina. Por outro lado, houve efeito quadrático no peso de carcaça, que foi melhor no nível de $1,07 \%$ de lisina digestível. No teor de proteína bruta do corpo vazio, a melhor resposta foi observada no nível 1,10\% de lisina dietetico. Esse mesmo nível correspondeu a resposta quadrática na deposição de água da carcaça e do corpo vazio. O nível de lisina digestível para melhor desempenho, composição química e deposição de nutrientes corporais em frangos de corte machos dos 23 aos 36 dias de idade situa-se entre 1,07 e 1,10\%.

Palavras-chave: aminoácido digestível, deposição de nutrientes, exigência, nutrição

\section{Introduction}

Because of the advances in genetic improvement, there is a constant need to reassess and to update the nutritional requirements of broiler chickens. These requirements are also associated with management, environment and health conditions in which birds are kept. Genetic gains in growth rates, feed conversion and carcass yield are constant challenges to nutrition because the genetic potential of the birds is influenced by other factors. Thus, to improve the performance of these birds, it is necessary to know the nutritional requirements under the continuous process of genetic improvement (Lana et al., 2005b).

Besides the genetic and environmental conditions, recommendations to meet amino acid requirements in different countries depend on food programs and criteria 
for response evaluations in the parameters of interest. In food programs, special attention is given to the ingredients used in diet, especially protein sources. Remarks to this effect were made in relation to the intake of lysine and its effects on performance and body composition of birds (D’Mello, 2003; Lana et al., 2005a; Toledo et al., 2007; Trindade Neto et al., 2009 and 2010). As for excess, a fraction of amino acid intake is catabolized and the rest are used for energy production or excreted as nitrogen. The eliminated part becomes pollutant as well as economic losses because of the cost of these nutrients in the diet. Thus, this study was carried out with the objective to determine the digestible lysine requirement for Ross broiler males from 23 to 36 days of age.

\section{Material and Methods}

The experiment was conducted at the Setor de Avicultura of the Departamento de Nutrição e Produção Animal (VNP-FMVZ), of Universidade de São Paulo, campus of Pirassununga, Brazil. The facilities were constituted of a masonry shed divided into 36 plots with $4.25 \mathrm{~m}^{2}$ each. The plots were equipped with tubular feeders, bell drinkers and floor covered with sawdust, and side windows and blinds to control the internal environment.

One thousand and fifty (1050) broilers, Ross, from 23 to 36 days of age were used to evaluate the effects of dietary lysine levels. The experimental design was randomized blocks with 5 levels of digestible lysine $(0.95 ; 1.00 ; 1.05$; 1.10; and 1.15\%). Each level was applied to seven replicates and the experimental unit was composed of 30 birds. Diets were offered in seven replicates and the experimental unit was represented by 30 birds. The diets had 19\% CP, $3,150 \mathrm{kcal}$ ME and were formulated with $0.95,1.00,1.05,1.10$, 1.15\% lysine (Table 1 ).

The diets were formulated based on the nutrient composition of ingredients presented by Rostagno et al. (2000). Diets were offered ad libitum to the birds; however, they were guided by the technical manual of genetic lineage (Agroceres, 2004). The average feed intake was established by the difference between the amount offered in the experimental period and the remnant amount at the end of the studied phase. The ratios between the other amino acids and lysine followed the guidelines of Rostagno et al. (2005).

Before the experimental period, birds in this study were fed a control diet formulated to meet the nutritional requirement of the strain which was: 3,050 kcal ME; $21 \% \mathrm{CP}$; $0.95 \%$ calcium; $0.45 \%$ available phosphorus; 0.22 sodium; $1.1 \%$ digestible lysine.
On the performance evaluation, it had been considered the final average weight, weight gain, relative weight gain, feed intake and feed conversion. The relative weight gain was defined as the ratio between weight gain achieved at the end of the experimental period divided by the weight of the bird at the beginning of the phase, expressed as a percentage. Feed intake was adjusted according to the mortality from each experimental unit. The intakes of lysine, metabolizable energy and lysine metabolizable energy ratio were obtained from food consumption data obtained during the experimental period and from the diet calculated composition.

For analysis of chemical composition, percentages of water, protein, lipid and ash of blood and viscera, carcass and empty body were considered. From the composition, it was determined deposition rates of water, protein, lipid and mineral in carcass and empty body, and protein/protein and water/lipids ratios were calculated.

On the first day of the experiment, 8 birds were randomly sampled and slaughtered for comparative purposes. The fractional blood, viscera and carcass were separated. After processing and chemical analysis of body fractions, the amounts of protein, water, lipid and ash were used as parameters for determining the chemical composition and deposition of body nutrients at the end of experiment. The data of body composition on the first day of the experiment were used to calculate the deposition of nutrients at the end of evaluation period.

At the end of the experiment, two birds that represented the final average weight of each plot were selected and slaughtered for determination of chemical composition and deposition of body nutrients.

For slaughter, it was adopted the method of bleeding, in which blood was collected in plastic bags. The viscera were removed and washed for their contents. After that, offal, which was considered as the digestive tract, reproductive organs, heart, liver, spleen, lungs, kidneys, glands and adjacent fat and blood became the fraction of offal and blood, respectively. After complete bleeding and gutted, chicken remaining with head, feet and feathers were considered as carcass. After identification, offal and carcass were weighed and frozen.

The empty body was defined as the difference between body weight and gastrointestinal content which was numerically close to the value of the reconstituted body weight, defined as the sum of fractions carcass, blood and offal. The difference between fasting body weight and reconstituted body weight was considered such as gastrointestinal contents and water lost by evaporation or in packaging pre-and postprocessing (Trindade Neto et al., 2009). 
Table 1 - Composition of experimental diets provided from 23 to 36 days of age

\begin{tabular}{|c|c|c|c|c|c|}
\hline & \multicolumn{5}{|c|}{ Digestible lysine (\%) } \\
\hline & 0.95 & 1.00 & 1.05 & 1.10 & 1.15 \\
\hline \multicolumn{6}{|l|}{ Ingredient (\%) } \\
\hline Soybean meal & 22.330 & 24.540 & 27.680 & 28.330 & 28.950 \\
\hline Soybean oil & 2.010 & 2.530 & 3.270 & 3.640 & 3.560 \\
\hline Gluten meal 60 & 5.000 & 3.450 & 1.200 & 0 & 0 \\
\hline L-threonine & 0.004 & 0.035 & 0.065 & 0.98 & 0.136 \\
\hline L-valine & 0 & 0 & 0 & 0.097 & 0.177 \\
\hline L-arginine & 0 & 0 & 0 & 0.050 & 0.165 \\
\hline L-isoleucine & 0 & 0 & 0 & 0 & 0.040 \\
\hline Salt & 0.430 & 0.430 & 0.430 & 0.430 & 0.430 \\
\hline Limestone & 1.020 & 1.010 & 1.000 & 0.990 & 0.990 \\
\hline \multicolumn{6}{|l|}{ Calculated nutrient composition } \\
\hline Metabolizable energy $(\mathrm{kcal} / \mathrm{kg})^{2}$ & 3150 & 3150 & 3150 & 3150 & 3150 \\
\hline Protein $(\%)^{2}$ & 19.00 & 19.00 & 19.00 & 19.00 & 19.00 \\
\hline Calcium $(\%)^{2}$ & 0.90 & 0.90 & 0.90 & 0.90 & 0.90 \\
\hline Available phosphorus $(\%)^{2}$ & 0.42 & 0.42 & 0.42 & 0.42 & 0.42 \\
\hline Sodium $(\%)^{2}$ & 0.19 & 0.19 & 0.19 & 0.19 & 0.19 \\
\hline Total lysine $(\%)^{3}$ & 1.09 & 1.13 & 1.16 & 1.23 & 1.25 \\
\hline Digestible lysine $(\%)^{2}$ & 0.95 & 1.00 & 1.05 & 1.10 & 1.15 \\
\hline Total methionine + cysteine $(\%)^{3}$ & 0.79 & 0.83 & 0.84 & 0.86 & 0.91 \\
\hline Digestible Methionine + cysteine $(\%)^{2}$ & 0.71 & 0.75 & 0.79 & 0.82 & 0.86 \\
\hline Total threonine $(\%)^{3}$ & 0.76 & 0.80 & 0.81 & 0.81 & 0.84 \\
\hline Digestible threonine $(\%)^{2}$ & 0.62 & 0.65 & 0.68 & 0.71 & 0.75 \\
\hline Digestible isoleucine $(\%)^{2}$ & 0.74 & 0.74 & 0.74 & 0.74 & 0.77 \\
\hline
\end{tabular}

By using the procedures described by AOAC (1984) chemical analyzes of samples from food and feedstuffs were performed. Frozen samples of body fractions were reduced to a paste with the aid of a meat grinder. Next, four samples from each body fraction were stored in Petri dishes for subsequent lyophilization (Leme et al., 1994, Shields et al, 1993).

The freeze drying occurred in Stokes model equipment, vacuum system at $3 \mathrm{~mm} \mathrm{Hg}$ of maximum pressure at $-15^{\circ} \mathrm{C}$ as initial temperature and final temperature of $10^{\circ} \mathrm{C}$. This process was carried out by sublimation. The dried samples were ground separately in a blender with dry ice for further analysis, in duplicate, in the Laboratório de Bromatologia da FMVZ-USP.
It was considered on the analysis of chemical composition the following contents: water, protein, lipid and ash, expressed in percentages in fractions of blood and offal, carcass and empty body. The data were expressed on fresh matter, dry matter corrected by $105^{\circ}$ to avoid errors due to reabsorption of water during processing. Deposition rates of water, protein, lipid and mineral were determined on carcass and empty body at the end of the experimental period. These rates were obtained from the difference between initial chemical composition at 23 days of age and at the 36 days of age. The determinations of ether extract, crude protein and ash were in accordance to AOAC (1984).

Normality of residuals (Shapiro-Wilk test) and variance homogeneity of data for all variables were verified. The data 
were analyzed by regression using SAS (1996), by the General Linear Models and means were compared by orthogonal contrast.

\section{Results and Discussion}

During performance evaluation (Table 2), the average temperature in the shed were $29.5^{\circ} \mathrm{C}$ (maximum) and $23.7^{\circ} \mathrm{C}$ (minimum), and a quadratic $(\mathrm{P}<0.05)$ response to lysine level on body weight of chickens at the end of the experiment occurred. The weight variation occurred according to the equation $\ddot{Y}=-1622.36+6602.5422 \mathrm{X}-3019.1834 \mathrm{X}^{2 *}, \mathrm{R}^{2}=86.76$ and $1.09 \%$ level of lysine was indicated as optimal. As observed for final weight, weight gain ( $\ddot{\mathrm{Y}}=-2489.08+$ $\left.6596.5735 \mathrm{X}-3028.5724 \mathrm{X}^{2 * *}, \mathrm{R}^{2}=83.87\right)$ and feed conversion $\left(\ddot{\mathrm{Y}}=8.55-12.4257 \mathrm{X}+5.6735 \mathrm{X}^{2 * *}, \mathrm{R}^{2}=89.56\right)$, also had quadratic responses $(\mathrm{P}<0.05)$, estimating the same level (1.09\%) of lysine as the best.

The weight gain of the birds, due to the increase of dietary lysine levels, coincided with the intake estimated between 18.5 and $22.1 \mathrm{~g}$, from the lowest to the highest level of inclusion in the diet (obtained from the composition calculated). In the setting of the proportional gain, through the relative weight gain, according to the quadratic equation $\ddot{Y}=-1.8115+7.5057 X-3.4694 * X^{2}\left(R^{2}=78.21\right), 1.08 \%$ of lysine was suggested at optimal level, confirming earlier observations.

Feed intake was not affected by dietary levels of amino acid, confirming the data reported by Valerio et al. (2003) and Trindade Neto et al. (2010), when studying levels of lysine for broilers from 22 to 42 days of age. Consumption data, depending on the levels of lysine are controversial, however. Borges et al. (2002) and Valerio et al. (2003), using birds at similar ages to this study and from several lineages, found no effect of lysine level on consumption. Other authors found that gradual increasing dietary lysine for chickens of different ages affected negatively feed intake (Fatufe et al. 2004; Sklan \& Noy, 2004; Namazu et al., 2008). The responses suggest a level similar to that indicated by Rostagno et al. (2005), 1.099\% of digestible lysine for broiler chickens with great performance between 22 to 33 days of age. Similar value was proposed by Lana et al. (2005b) who suggested $1.075 \%$ lysine, based on final weight and weight gain of broilers from 22 to 42 days of age maintained under thermo neutral environment.

In this study, however, the results were different from those obtained by Amarante Junior et al. (2005), who suggested $1.03 \%$ digestible lysine for broilers from 22 to 42 days of age, and by Costa et al. (2001), who indicated $1.044 \%$ digestible lysine for broiler chickens of the same strain from 22 to 40 days of age. As indicated in this study, the optimum level is about $20 \%$ higher than the suggested in the technical manual line used (Agroceres, 2004), which suggests $0.92 \%$ digestible lysine for the period of 29 days of age until slaughter.

In the sampling of birds for carcass evaluation, it was observed a quadratic effect on slaughter weight (Table 3), which varied according to equation $\ddot{Y}=-3595.45+10174 X$ $-4725.9184 \mathrm{X}^{2 *}$, indicating the optimum level of lysine, $1.076 \%$. Yields of abdominal fat, liver, thigh + drumstick, wing, breast and carcass were not influenced by the level of dietary lysine. The absence of statistical differences in this variable was due probably to the genetic characteristics of chicken in response to nutrient levels studied. The variation of $17.4 \%$ from the lowest to the highest level of lysine studied corresponded to a $7 \%$ of increase in weight gain of the bird. This difference did not affect the efficiency of the broilers to convert dietary nutrients in proportional deposition of body tissues (fat and protein). Considering the range of lysine levels in this study and the range of feed conversion of $6.4 \%$, the results of carcass characteristics suggest possibility of diets manipulation according to feed

Table 2 - Performance of male broilers from 23 to 36 days of age receiving different levels of dietary lysine ${ }^{1}$

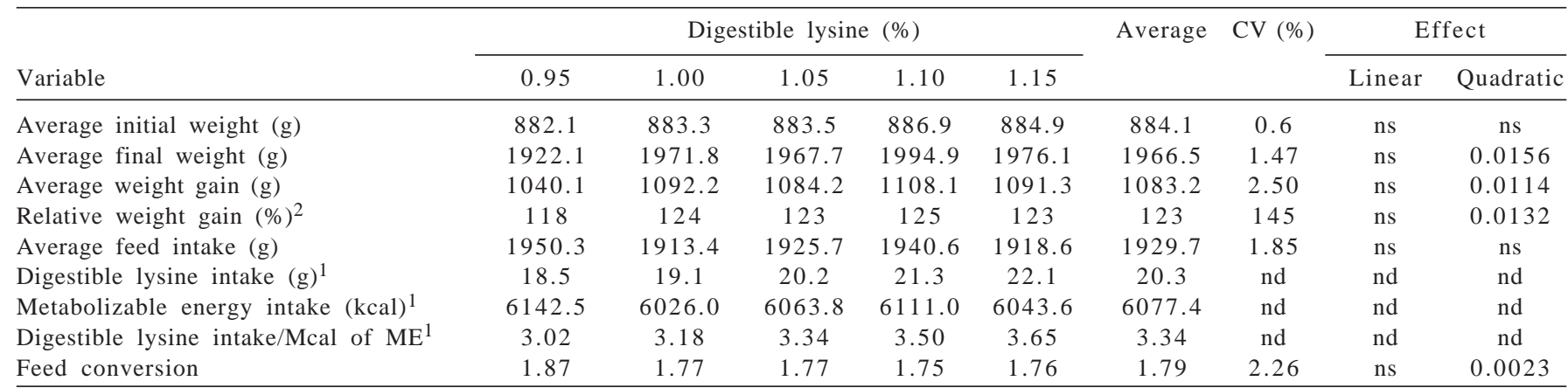

ns - not-significant ( $\mathrm{P}>0.10)$; nd - not-determined.

${ }^{1}$ Estimated based on the calculated composition of the diet.

${ }^{2}$ Average weight gain/average initial weight. 
cost and price of chicken paid for the farmers. Conhalato et al. (1999), studied the lysine requirement for broiler males from 22 to 42 days of age at levels from 0.80 to $1.02 \%$ and found no significant effects of lysine levels on carcass, breast and legs.

The results obtained for carcass traits and yield cuts differ from those found by Costa et al. (2001) in a similar study with broilers from the same lineage and age. These authors observed a linear increase in carcass and breast yield and a decreasing effect on abdominal fat in the extent to which increased the level of dietary lysine. In that study, proposed $1.04 \%$ digestible lysine requirement as Ross broiler males from 22 to 40 days old.

A quadratic effect $(\mathrm{P}<0.05)$ of lysine was observed on carcass weight $\left(\ddot{Y}=-3998.83+10525 X-4901.5286 X^{2^{*}}\right)$ and the level of digestible amino acid indicated as optimal level was $1.07 \%$, a value similar to slaughter weight, when the performance characteristics were evaluated (Table 4).

The lysine level produced a quadratic effect on water deposition on carcass $(\mathrm{P}<0.001)$ and empty body $(\mathrm{P}<0.05)$ (Table 5). After carcass water deposition, the variation of protein deposition rate among lysine levels suggests muscle mass accretion up to $1.10 \%$ of lysine, and both are associated with deposition. The efficiency of carcass protein deposition could be confirmed by the ratio between protein and lipid (fat) accumulation. The results in this variable corresponded to the same variations of carcass weight and water deposition, although the coefficient of variation was higher, not allowing the characterization of the statistical effect. Based on these results, the ascendancy and the highest value for protein/lipid ratio also suggest a better response at the level of $1.10 \%$ digestible lysine.

Table 3 - Characteristics of carcass and cut yields of broiler chickens at 36 days of age receiving different levels of dietary lysine

\begin{tabular}{|c|c|c|c|c|c|c|c|c|c|}
\hline \multirow[b]{2}{*}{ Variable } & \multicolumn{4}{|c|}{ Digestible lysine (\%) } & \multirow{2}{*}{$\begin{array}{c}\text { Mean } \\
1.15 \\
\end{array}$} & \multirow[t]{2}{*}{ CV (\%) } & & \multicolumn{2}{|c|}{ Effect } \\
\hline & 0.95 & 1.00 & 1.05 & 1.10 & & & & Linear & Quadratic \\
\hline Slaugther weight $(\mathrm{g})^{1}$ & $2,017.60$ & $2,037.40$ & $2,037.10$ & $2,094.50$ & $2,053.80$ & $2,048.10$ & 2.37 & 0.0334 & 0.05 \\
\hline Yield & & & & & & & & & \\
\hline Abdominal fat (\%) & 1.35 & 1.09 & 1.17 & 1.27 & 1.22 & 1.21 & 15.30 & ns & ns \\
\hline Liver (\%) & 2.32 & 2.23 & 2.31 & 2.21 & 2.26 & 2.21 & 5.44 & ns & ns \\
\hline Thigh + drumstick (\%) & 27.50 & 27.60 & 27.40 & 27.60 & 27.80 & 27.60 & 1.76 & ns & ns \\
\hline Wing (\%) & 10.70 & 10.70 & 11.10 & 10.80 & 10.80 & 10.80 & 2.5 & ns & ns \\
\hline Breast (\%) & 31.00 & 30.80 & 30.80 & 30.70 & 30.80 & 30.80 & 1.9 & ns & ns \\
\hline Carcass (\%) & 78.90 & 79.30 & 78.90 & 78.90 & 79.40 & 79.10 & 0.85 & ns & ns \\
\hline
\end{tabular}

1 Two chickens sampled per plot, totaling 14/lysine level.

ns - not significant $(\mathrm{P}>0.10)$.

Table 4 - Chemical composition of empty body and body fractions of broilers chickens at 23 days of age ${ }^{1}$

\begin{tabular}{|c|c|c|c|c|c|c|c|c|c|}
\hline \multirow[b]{2}{*}{ Variable } & \multicolumn{5}{|c|}{ Digestible lysine (\%) } & \multirow[t]{2}{*}{ Mean } & \multirow[t]{2}{*}{ CV (\%) } & \multicolumn{2}{|c|}{ Effect } \\
\hline & 0.95 & 1.00 & 1.05 & 1.10 & 1.15 & & & Linear & Quadratic \\
\hline Blood and offal (g) & 216.28 & 224.00 & 210.86 & 223.00 & 221.14 & 219.06 & 8.18 & ns & ns \\
\hline Carcass weight (g) & $1,583.59$ & $1,641.90$ & $1,652.99$ & $1,657.93$ & $1,633.55$ & $1,634.00$ & 3.08 & ns & 0.042 \\
\hline Reconstituted body weight $(g)^{2}$ & $1,799.87$ & $1,865.90$ & $1,863.85$ & $1,880.93$ & $1,854.69$ & $1,853.05$ & 3.02 & ns & 0.0474 \\
\hline \multicolumn{10}{|l|}{ Blood and offal } \\
\hline Water (\%) & 74.85 & 75.70 & 75.63 & 75.82 & 76.32 & 75.66 & 2.13 & ns & ns \\
\hline Crude protein (\%) & 15.87 & 15.84 & 15.84 & 16.44 & 15.80 & 15.96 & 4.78 & ns & ns \\
\hline Lipid (\%) & 7.96 & 7.22 & 7.22 & 6.43 & 6.65 & 7.09 & 26.61 & ns & ns \\
\hline Ash (\%) & 1.40 & 1.24 & 1.31 & 1.30 & 1.29 & 1.31 & 10.98 & ns & ns \\
\hline \multicolumn{10}{|l|}{ Carcass $^{3}$} \\
\hline Water (\%) & 68.11 & 69.13 & 69.26 & 68.75 & 69.12 & 68.87 & 1.35 & ns & ns \\
\hline Crude protein (\%) & 16.49 & 16.53 & 16.21 & 16.67 & 16.38 & 16.46 & 4.04 & ns & ns \\
\hline Lipid (\%) & 11.12 & 10.30 & 9.97 & 10.57 & 10.53 & 10.50 & 11.32 & ns & ns \\
\hline Ash (\%) & 4.29 & 4.04 & 4.18 & 4.02 & 3.96 & 4.09 & 10.94 & ns & ns \\
\hline \multicolumn{10}{|l|}{ Empty body } \\
\hline Water (\%) & 68.91 & 69.92 & 70.87 & 69.57 & 69.99 & 69.85 & 1.98 & ns & ns \\
\hline Crude protein (\%) & 16.42 & 16.45 & 16.17 & 16.65 & 16.31 & 16.40 & 3.67 & ns & ns \\
\hline Lipid (\%) & 10.74 & 9.93 & 9.66 & 10.08 & 10.06 & 10.09 & 11.34 & ns & ns \\
\hline Ash (\%) & 3.93 & 3.70 & 3.85 & 3.70 & 3.63 & 3.76 & 10.72 & ns & ns \\
\hline
\end{tabular}

ns - not-significant.

${ }^{1}$ Data expressed in percentage as fed.

2 Reconstituted body weight - sum of fractions blood, offal and carcass.

${ }^{3}$ Carcass - with head, feet and feathers. 
Table 5 - Chemical composition of carcass and empty body of broilers from 23 to 36 days of age ${ }^{1}$

\begin{tabular}{|c|c|c|c|c|c|c|c|c|c|}
\hline \multirow[b]{2}{*}{ Variable } & \multicolumn{5}{|c|}{ Digestible lysine (\%) } & \multirow[t]{2}{*}{ Mean } & \multirow[t]{2}{*}{ CV (\%) } & \multicolumn{2}{|c|}{ Effect } \\
\hline & 0.95 & 1.00 & 1.05 & 1.10 & 1.15 & & & Linear & Quadratic \\
\hline \multicolumn{10}{|l|}{ Carcass deposition $^{2}$} \\
\hline Water (g) & 635.85 & 692.23 & 697.09 & 696.13 & 686.17 & 681.49 & 4.99 & ns & 0.0083 \\
\hline Crude protein (g) & 163.68 & 165.54 & 166.22 & 170.11 & 161.75 & 165.46 & 5.40 & ns & ns \\
\hline Ether extract (g) & 118.58 & 111.96 & 107.86 & 118.82 & 114.92 & 114.43 & 18.08 & ns & ns \\
\hline Water (g) & 700.92 & 765.03 & 781.07 & 768.53 & 758.36 & 754.78 & 6.14 & ns & 0.0125 \\
\hline Crude protein (g) & 169.65 & 180.98 & 174.71 & 186.68 & 176.64 & 177.73 & 6.82 & ns & ns \\
\hline Ether extract (g) & 130.29 & 122.55 & 117.63 & 127.56 & 123.83 & 124.37 & 17.79 & ns & ns \\
\hline Ash (g) & 42.79 & 41.19 & 44.04 & 41.87 & 39.73 & 41.93 & 19.25 & ns & ns \\
\hline \multicolumn{10}{|l|}{ Ratio } \\
\hline
\end{tabular}

ns - not-significant.

${ }^{1}$ Data expressed in percentage as fed.

2 Carcass: with head, feet and feathers.

\section{Conclusions}

The level of digestible lysine for better performance, chemical composition and body nutrient deposition in broilers from 23 to 36 days of age is between 1.07 and $1.10 \%$.

\section{Acknowledgments}

Agroceres Ross, Ajinomoto Biolatina Indústria e Comércio Ltda, Nutron Alimentos and Fundação de Apoio à Pesquisa Agrícola - FUNDAG, Campinas - SP, by partial funding of the project.

\section{References}

AGROCERES [2004] Manual de manejo de frangos AGRoss. Disponível em: <http://www.agroceresross.com.br/servlet/ navSrvt?cmd=list PublicacaoFrango\&id=47>. Acesso em: 14/1/2006.

AMARANTE JUNIOR, V.S.; COSTA, F.G.P.; BARROS, L.R. et al. Níveis de lisina para frangos de corte nos períodos de 22 a 42 e de 43 a 49 dias de idade, mantendo a relação metionina + cistina. Revista Brasileira de Zootecnia, v.34, n.4, p.1188-1194, 2005.

ASSOCIATION OF OFFICIAL ANALYTICAL CHEMISTRY AOAC. Official methods of analysis. 14.ed. Arlington: Association of Official Analytical Chemists, 1984. 972p.

BORGES, A.F.; OLIVEIRA, R.F.M.; DONZELE, J.L. et al. Exigência de Lisina para frangos de corte machos no período de 22 a 42 dias de idade, mantidos em ambiente quente $\left(26^{\circ} \mathrm{C}\right)$. Revista Brasileira de Zootecnia, v.31, n.5, p.1993-2001, 2002.

CONHALATO, G.S.; DONZELE, J.L.; ALBINO, L.F.T. et al. Níveis de lisina digestível para frangos de corte machos na fase de 22 a 42 dias de idade. Revista Brasileira de Zootecnia, v.28, n.1, p.98-104, 1999

COSTA, F.G.P.; ROSTAGNO, H.S.; ALBINO, L.F.T. et al. Níveis dietéticos de lisina para frangos de corte de 1 a 21 e 22 a 40 dias de idade. Revista Brasileira de Zootecnia, v.30, n.5, p.1490-1497, 2001.
D'MELLO, J.P.F. Responses of growing poultry to amino acids. In: Amino acids in animal nutrition. 2.ed. Edinburgh: CABI Publishing, 2003. p.237-263.

FATUFE, A.A.; TIMMLER, R.; RODEHUTSCORD, M. Response to lysine intake in composition of body weight gain and efficiency of lysine utilization of growing male chickens from two genotypes. Poultry Science, v.83, n.8, p.1314-1324, 2004.

LANA, S.R.V.; OLIVEIRA, R.F.M.; DONZELE, J.L. et al. Níveis de lisina digestível em rações para frangos de corte de 1 a 21 dias de idade, mantidos em ambiente de termoneutralidade. Revista Brasileira de Zootecnia, v.34, n.5, p.1614-1623. 2005 a.

LANA, S.R.V.; OLIVEIRA, R.F.M.; DONZELE, J.L. et al. Níveis de lisina digestível em rações para frangos de corte de 22 a 42 dias de idade, mantidos em ambiente de termoneutralidade. Revista Brasileira de Zootecnia, v.34, n.5, p.1624-1632. 2005b.

LEME, P.R.; BOIN, C.; ALLEONI, G.F. et al. Estimativa da composição química corporal de novilhos nelore através do espaço de deutério. Revista Brasilera de Zootecnia, v.23, n.3, p.441-452, 1994.

MENDES, A.A.; WATKINS, S.E.; ENGLAND, J.A.O. et al. Influence of dietary lysine levels and arginine: lysine ratios on performance of broilers exposed to heat or cold stress during the period of three to six weeks of age. Poultry Science, v.76, n.3, p.472-481, 1997.

NAMAZU, L.B.; KOBASHIGAWA, E.; ALBUQUERQUE, R. et al. Lisina digestível e Zn quelado para frangos de corte machos: desempenho e retenção de nitrogênio na fase pré-inicial. Revista Brasileira de Zootecnia, v.37, n.9, p.1634-1640, 2008.

ROSTAGNO, H.S.; ALBINO, L.F.T.; DONZELE, J.L. et al. Composição de alimentos e exigências nutricionais. (Tabelas Brasileiras para Aves e Suínos). Viçosa, MG: UFV, 2005. 186p.

ROSTAGNO, H.S.; SILVA, D.J.; COSTA, P.M.A. et al. Composição de alimentos e exigências nutricionais de aves e suínos. (Tabelas Brasileiras). Viçosa, MG: UFV, 2000. 141p.

SKLAN, D.; NOY, Y. Catabolism and deposition of amino acids in growing chicks: effect of dietary supply. Poultry Science, v.83, n.6, p.952-961, 2004.

TOLEDO, A.L.; TAKEARA, P.; KOBASHIGAWA, E. et al. Níveis dietéticos de lisina digestível para frangos de corte machos no 
período de 1 a 11 dias de idade: desempenho e composição corporal. Revista Brasileira de Zootecnia, v.36, n.4, p.1090-1096, 2007 (supl.).

TRINDADE NETO, M.A., TAKEARA, P., TOLEDO, A.L. et al. Níveis de lisina digestível para frangos de corte machos no período de 37 a 49 dias de idade. Revista Brasileira de Zootecnia, v.38, n.3, p.508-514, 2009.

TRINDADE NETO, M.A., KOBASHIGAWA, E., NAMAZU, L.B. et al. Lisina digestível e zinco orgânico para frangos de corte machos na fase de 22 a 42 dias de idade. Revista Brasileira de Zootecnia, v.39, n.11, p.2460-2470, 2010.
SHIELDS, R.G.; MAHAN JR., D.C.; GRAHAM, P.L. Changes in swine body composition from birth to $145 \mathrm{~kg}$. Journal of Animal Science, v.57, p.43?54, 1993.

STATISTICAL ANALYSES SYSTEM - SAS. User's guide: statistics. 12.ed. New York: SCOTT, M.L. \& Associates, 1996. $511 \mathrm{p}$.

VALÉRIO, S.R.; OLIVEIRA, R.F.M.; DONZELE, J.L. et al. Níveis de lisina digestível em rações, mantendo ou não a relação aminoacídica, para frangos de corte de 22 a 42 dias de idade, sob condições de estresse por calor. Revista Brasileira de Zootecnia, v.32, n.2, p.372-382, 2003. 